\title{
Representasi Feminisme Dalam Karakter Pahlawan Perempuan Captain Marvel
}

\author{
Naurissa Biasini ${ }^{1}$, Sri Wijayanti ${ }^{2}$ \\ ${ }^{1}$ Program Studi Ilmu Komunikasi, Universitas Pembangunan Jaya \\ Tangerang Selatan, Banten 15413, Indonesia \\ ${ }^{2}$ Program Studi Ilmu Komunikasi, Universitas Pembangunan Jaya \\ Tangerang Selatan, Banten 15413, Indonesia \\ Email korespondensi: naurissa.biasini@upj.ac.id
}

Received 31 December 2020, Revised 24 March 2021, Accepted 11 May 2021

\begin{abstract}
One of the film genres with an extraordinary development is film with the theme of heroism. Various film producer companies such as Marvel Entertainment, Warner Brothers, and Disney are competing to produce hero-themed films that always attract the attention of the audience. However, Marvel Entertainment has put more emphasis on male hero characters, until in 2019 there is a female hero character who has her own film, Captain Marvel. This is interesting because usually women in films are shown only as supporting characters for male heroes. Therefore, this study aims to see how feminism is represented in the character of Captain Marvel. This study will use Roland Barthes' Semiotics research method to see the symbols used to describe the values of Feminism displayed by this character, supported by Communication Theory and Feminism Theory related to mass media, especially films. The results showed that the character of Captain Marvel is depicted as a female figure who has greater strength than men and shows some values of radical and liberal feminism. In the film, Marvel Entertainment unfortunately has to show that Captain Marvel must have super power before recognized or considered superior to men.
\end{abstract}

Keywords: Film, Feminism, Captain Marvel, Captain Marvel, Roland Barthes Semiotic

\begin{abstract}
Abstrak - Salah satu genre film dengan perkembangan yang luar biasa adalah film yang bertemakan kepahlawanan. Berbagai perusahaan produsen film seperti Marvel Entertainment, Warner Brothers, hingga Disney berlomba-lomba menghasilkan film-film bertema kepahlawanan yang selalu menarik perhatian penonton. Namun selama ini Marvel Entertainment lebih menekankan pada tokoh-tokoh pahlawan pria, hingga pada tahun 2019 ada karakter pahlawan perempuan yang memiliki filmnya sendiri yaitu Captain Marvel. Hal ini menarik karena biasanya perempuan dalam film ditampilkan hanya sebagai karakter pendukung pahlawan pria. Karena itu penelitian ini bertujuan untuk melihat bagaimana representasi Feminisme dalam sosok karakter Captain Marvel. Penelitian ini akan menggunakan metode penelitian Semiotika Roland Barthes untuk melihat simbol-simbol yang digunakan untuk menggambarkan nilai-nilai Feminisme saja yang ditampilkan oleh karakter tersebut, didukung dengan Teori Komunikasi dan Teori Feminisme yang berkaitan dengan media massa terutama film. Hasil Penelitian menunjukkan bahwa karakter Captain Marvel digambarkan sebagai sosok perempuan yang memiliki kekuatan yang besar dari laki-laki dan menunjukkan beberapa nilai feminism radikal maupun liberal. Dalam film yang diteliti, Marvel Entertainment sayangnya harus menampilkan Captain Marvel memiliki kekuatan super terlebih dahulu untuk dapat diakui atau dianggap lebih hebat dari pria.
\end{abstract}

Kata Kunci: Film, Feminisme, Captain Marvel, Semiotika Roland Barthes

\section{PENDAHULUAN}

Berbagai perusahaan produsen film seperti Marvel Entertainment, Warner Brothers, hingga Disney berlomba-lomba menghasilkan film-film bertema kepahlawanan yang selalu menarik perhatian penonton. Sejak tahun 1978-2018, penghasilan dari film yang bertemakan kepahlawanan semakin meningkat, hingga mencapai pemasukan total hingga sebesar lebih dari 2,8 Milyar Dollar di tahun 2018 saja (Watson, 2020). Hal ini menunjukkan bahwa film bertemakan kepahlawanan memiliki penggemar dan penonton yang besar di seluruh dunia.

Salah satu perusahaan produsen film bertemakan kepahlawanan yang digemari di seluruh 
dunia adalah Marvel Entertainment. Perusahaan ini adalah anak perusahaan The Walt Disney Company, merupakan salah satu perusahaan hiburan terkemuka, yang memiliki lebih dari 8000 karakter ciptaan yang hadir dalam berbagai media selama lebih dari 75 tahun (Marvel, 2020). Dengan jumlah karakter yang begitu banyak dan jalan cerita yang kompleks, Marvel Entertainment menciptakan Marvel Cinematic Universe (MCU) dengan Iron Man sebagai film pertama mereka (Movieweb, 2010).

Hingga tahun 2020 ini, Marvel Cinematic Universe telah memproduksi 24 film yang keseluruhnya merupakan film dengan tema kepahlawanan dan menghadirkan berbagai pahlawan super seperti Iron Man, Spiderman, Captain America, Thor, dan lain sebagainya (Marvel, 2020). Kesuksesan ini tentunya juga dikarenakan banyaknya jumlah penonton yang setia mengikuti perkembangan cerita dalam Marvel Cinematic Universe.

Namun sayangnya, dalam fim-film produksi Marvel Entertainment, sebagian besar karakter yang ditampilkan sebagai tokoh utama ataupun pahlawan adalah karakter pria. Hanya sebagian kecil karakter perempuan yang muncul sebagai pahlawan. Bahkan dalam keseluruhan produksi Marvel Entertainment hingga tahun 2019, hanya ada satu karakter pahlawan perempuan yang memiliki filmnya sendiri yaitu Captain Marvel, meskipun sebenarnya jumlah pahlawan perempuan yang muncul dalam komik sebenarnya meningkat.

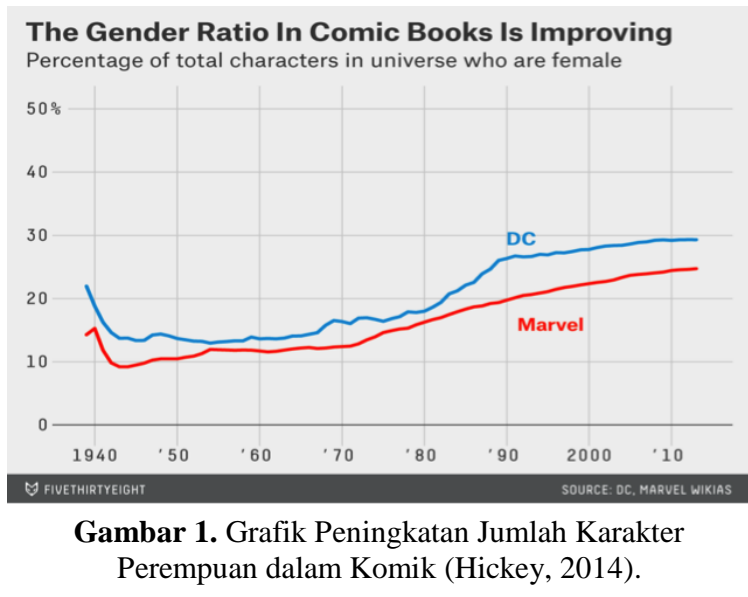

Irawan (2014) menyatakan bahwa representasi perempuan di industri perfilman, baik nasional maupun internasional, lebih sering mendapatkan stereotip yang negatif dibandingkan positif. Perempuan sering dianggap hanya menjual kecantikan, keseksian, dan tingkah laku yang diinginkan laki-laki saat tampil di layar lebar. Sedangkan Thornham dalam Gamble (2010) menyatakan bahwa perempuan sering kali ditindas dalam dunia perfilman dengan memerankan citra sebagai objek seks, korban atau kaum yang lemah, hingga sosok penggoda laki-laki. Hal ini pun terjadi pada karakter perempuan yang menjadi tokoh utama dalam sebuah film, baik film bergenre drama maupun aksi. Sering kali perempuan ditampilkan membutuhkan bantuan dari sosok laki-laki dalam film tersebut.

Hingga pada tahun 2019, Marvel Studio menayangkan film Captain Marvel dan Infinity War: End Game yang akan menampilkan sosok Captain Marvel sebagai superhero terkuat dari Marvel Universe di mana menariknya superhero yang diangkat adalah sosok perempuan. Perempuan biasanya diangkat dalam bentuk tokoh yang lemah lembut, seorang ibu rumah tangga, ibu dari anakanak, dan orang yang membutuhkan pria dalam hidupnya. Namun, dalam film ini, Captain Marvel menceritakan sosok pahlawan perempuan yang kekuatannya sangat besar.

Adanya film ini bahkan seperti membantah anggapan bahwa superhero perempuan tidak bisa menjadi benar-benar superhero yang bisa secara mandiri mengalahkan musuh-musuhnya. Jika dibandingkan dengan film-film superhero perempuan lainnya seperti Wonder Woman, cat woman, dan lain sebagainya. Tokoh perempuan di sana masih digambarkan memiliki rasa jatuh cinta dan masih memiliki ketergantungan pada laki-laki. Hal ini berbeda dengan kemunculan film Captain Marvel yang mungkin mengubah pandangan masyarakat tentang tokoh superhero perempuan. Dalam filmnya, Captain Marvel adalah sosok yang maskulin, sangat kuat, mandiri, tangguh, tidak tergantung pada orang lain. Bahkan tidak ada cerita tentang percintaan antara Captain Marvel dengan laki-laki siapapun. Hal inilah yang menarik sehingga penelitian ini dilakukan untuk mengetahui nilai-nilai feminisme seperti apa yang digambarkan dari setiap adegan pada film Captain Marvel yang mengarah pada pandangan masyarakat tentang tokoh superhero perempuan saat ini. Hal ini menjadi menarik perhatian karena Captain Marvel adalah sosok pahlawan perempuan pertama dalam Marvel Cinematic Universe yang memiliki filmnya sendiri dan menjadi sosok dengan kekuatan super yang dikatakan melebihi kekuatan super pahlawan pria lainnya.

Ketika membicarakan penggambaran sosok perempuan dalam media, akan berkaitan erat dengan konsep feminitas dan teori-teori feminisme. Penelitian mengenai media feminis belakangan ini telah bergeser dari ketertarikan dalam mengkritisi stereotip gender menjadi melihat pada bagaimana penggambaran wanita dalam media dipahami oleh penonton. Menurut Hermes dalam McQuail (2010) kita perlu memahami bagaimana media merepresentasikan gender karena konstruksi feminitas dan maskulinitas adalah bagian dari ideologi dominan. Ia juga menulis bahwa media masih menawarkan panduan dan contoh bagaimana perilaku wanita seharusnya. McQuail (2010) menyatakan ada dua isu penting yang muncul dalam 
kritik feminis, yaitu sejauh mana teks media yang ditujukan untuk hiburan bagi wanita dapat memberikan perasaan terbebas meskipun teks tersebut mewujudkan realitas masyarakat patriarkal dan lembaga keluarga. Selanjutnya adalah sejauh mana teks-teks media massa ini menolak stereotip gender dan mencoba memperkenalkan bagaimana model peran positif dapat memiliki efek pemberdayaan bagi perempuan.

Dalam Feminisme, terdapat berbagai macam teori yang menjadi dasar pergerakan feminisme di dunia. Dua teori yang menjadi fokus utama dalam penelitian ini untuk melihat representasi feminisme dalam karakter Captain Marvel adalah Feminisme Liberal dan Feminisme Radikal. Rokhmansyah (2016) menyatakan bahwa dasar aliran Feminisme Liberal adalah ini adalah bahwa setiap manusia memiliki hak asasi yaitu hak untuk hidup, hak mendapatkan kebebasan dan hak untuk mencari kebahagiaan. Kemudian Ilyas dalam Rokhmansyah (2016) menyatakan bahwa Feminisme Liberal beranggapan bahwa sistem patriarki dapat dihancurkan dengan cara mengubah sikap masingmasing individu, terutama sikap kaum perempuan dalam hubungannya dengan laki-laki. Kaum feminis liberal menentang pandangan biologisme yang menganggap perbedaan antara laki-laki dan perempuan berpangkal pada perbedaaan biologis. Untuk menghilangkan diskriminasi dan ketimpangan sosial, perempuan harus diberikan kesempatan seluas-luasnya untuk mendapatkan pendidikan dan kesempatan kerja. Inti utama dalam Feminisme Liberal adalah kesetaraan antara laki-laki dan perempuan dalam berbagai bidang.

Sedangkan dalam Feminisme Liberal, penindasan terhadap perempuan berakar pada ideologi patriarki yang mengatur laki-laki dan perempuan secara umum (Sunarto, 2000). Menurut Jones, Bradbury, dan Buotillier (2016) patriarki merupakan bentuk kekuasaan laki-laki atas perempuan; bagi feminis radikal, laki-lakilah yang menindas perempuan, bukan sistem ekonomi. Selanjutnya Bouchier dalam Jones, Bradbury, dan Buotillier (2016) menyatakan bahwa adanya pendapat dari feminis radikal bahwa perkawinan adalah sumber institusional dari eksploitasi oleh lakilaki terhadap perempuan. Ekploitasi ini juga ditemukan dalam pekerjaan, pendidikan, media dan seterusnya.

Karena itu Murniati (2004) menyatakan bahwa untuk membebaskan kaum perempuan dari kondisi patriarki ini, maka kekuasaan pria harus dihapuskan dengan cara menghapus perbedaan status, peran, dan temperamen mereka yang didasari oleh jenis kelamin. Kekerasan seksual (sexual harassment) hingga eksploitasi perempuan secara seksual dalam pornografi merupakan beberapa hal yang ditentang oleh feminisme radikal. Bahkan aliran ini menganjurkan gaya hidup lesbian karena menurut Rokhmansyah (2016) perempuan lesbian merupakan model perempuan mandiri yang terbebas dari dominasi laki-laki. Dari dua teori feminisme di atas, dapat dilihat bahwa Feminisme Liberal menuntut adanya kesetaraan, sedangkan Feminisme Radikal menginginkan hilangnya patriarki, dengan menghilangkan kekuasaan laki-laki, bahkan untuk tidak memiliki hubungan romantis dengan laki-laki.

Selain Teori Feminisme, konsep Feminitas juga sering kali dikaitkan dalam penelitian media feminis. Wijngaarg dalam Brownmiller (2013) menyatakan "Femininity is a set of attributes, behaviors, and roles generally associated with girls and women. Femininity is often perceived as a social construct, which is made up of both socially defined and biologically created factors." Berdasarkan pernyataan ini, dapat dilihat bahwa feminitas merupakan seperangkat ciri, perilaku dan peran yang secara umum dikaitkan dengan anak perempuan dan wanita. Feminitas adalah sebuah konstruksi yang diciptakan berdasarkan faktor sosial dan faktor biologis. Menurut Hollows (2010) feminitas dipandang sebagai penyebab utama penindasan yang dialami oleh perempuan. Brownmiller (2013) menyatakan bahwa feminitas dapat dilihat dalam beberapa kategori yaitu tubuh yang kecil dan ramping, rambut panjang dan pirang, pakaian yang sopan namun menggoda seperti rok, suara yang lembut dan terbungkam, kulit putih, gerakan yang gemulai dan halus, emosional, dan kurangnya ambisi. Beberapa kategori feminitas ini juga dapat digunakan untuk menilai apakah karakter perempuan dalam sebuah media dianggap feminin sehingga tidak menunjukkan Feminisme.

Berdasarkan hasil observasi peneliti, film Captain Marvel menceritakan tentang seorang pilot pesawat terbang bernama Carol Denvers yang kehilangan ingatan dan menjadi anggota pasukan bangsa Kree. Dalam sebuah misi, ia terdampar di bumi dan mencoba mencari jawaban atas jati dirinya yang sesungguhnya. Dalam filmnya, ia banyak melakukan adegan perkelahian, menerbangkan pesawat, mengalahkan banyak pasukan pria, hingga menghancurkan pesawat-pesawat yang dimiliki oleh pasukan Kree dengan kekuatan supernya.

Dalam filmnya, sosok Captain Marvel berdasarkan observasi awal tidak menunjukkan ciri feminitas yang digambarkan oleh Brownmiller sebagai perempuan feminin. Ia juga ditampilkan sebagai perempuan yang berusaha untuk sukses dalam pekerjaannya dan pantang menyerah. Karena itulah dibutuhkan penelitian dengan metode yang komprehensif untuk melihat bagaimana representasi feminisme dalam karakter Captain Marvel.

Untuk melihat representasi tersebut diperlukan juga rujukan terkait teknik sinematografi dalam film yang memiliki berbagai makna dari setiap teknik yang diterapkan. Beberapa teknik utama yang perlu dipahami adalah teknik ukuran pengambilan gambar, teknik arah pengambilan gambar, gerakan kamera, dan penggunaan warna. 


\section{METODE PENELITIAN}

Metode penelitian terbagi menjadi lokasi studi dan analisis data. Lokasi studi akan membahas mengenai metode penelitian yang digunakan, sedangkan analisis data membahas mengenai proses analisis semiotika menggunakan penanda, petanda, dan tanda baik denotatif maupun konotatif.

\section{Lokasi Studi}

Studi ini merupakan studi analisis teks kualitatif dengan menggunakan metode Semiotika Roland Barthes yang dilakukan di Tangerang Selatan. Metode semiotika tidak membutuhkan populasi atau sampel berupa manusia untuk menjadi objek penelitian. Yang menjadi objek dalam penelitian ini adalah Film Captain Marvel, di mana yang akan menjadi unit analisis adalah adegan atau scene dalam film. Dalam proses penelitian, diperlukan observasi awal dengan menonton film Captain Marvel, kemudian menentukan adegan-adegan atau scene yang menunjukkan tanda-tanda feminisme sesuai dengan teori dan konsep feminisme dan feminitas.

Dalam penelitian ini, terdapat 28 adegan atau scene yang menjadi unit analisis. Ke-28 scene tersebut kemudian dikelompokkan berdasarkan unit yang berkaitan dengan kepahlawanan tokoh wanita yaitu Captain Marvel. Melalui pengamatan langsung dari setiap tanda yang terdapat dalam film Captain Marvel baik dari segi non verbal maupun verbal.

\section{Analisis Data}

Model analisis semiotika Barthes menegaskan ke dalam konsep denotasi dan konotasi sebagai inti dari model analisisnya, di mana model tersebut populer disebut sebagai signifikasi dua tahap (two order of signification) (Sobur, 2017). Signifikasi tahap pertama merupakan hubungan antara signifier dan signified (makna denotasi). Pada tatanan ini menggambarkan relasi antara penanda (objek) dan petanda (makna) di dalam tanda, dan antara tanda dan dengan referannya dalam realitasnya eksternal. Hal ini mengacu pada makna sebenarnya (riil) dari penanda (objek). Sedangkan signifikasi tahap kedua adalah interaksi yang terjadi ketika tanda bertemu (makna konotasi).

Dalam istilah yang digunakan Barthes dalam Sobur (2017) konotasi dipakai untuk menjelaskan salah satu dari tiga cara kerja tanda (konotasi, mitos, dan simbol) dalam tatanan pertanda kedua (signifikasi tahap kedua). Konotasi menggambarkan interaksi yang berlangsung saat bertemu dengan perasaan atau emosi penggunanya dan nilai-nilai kulturalnya. Bagi Barthes, faktor penting dalam konotasi adalah penanda dalam tatanan pertama dalam peta Roland Barthes. Konotasi bagi Barthes justru mendenotasikan sesuatu hal yang ia nyatakan sebagai mitos, dan mitos ini mempunyai konotasi terhadap ideologi tertentu. Skema pemaknaan mitos itu oleh Barthes digambarkan sebagai berikut :

\begin{tabular}{|l|l|l|}
\hline $\begin{array}{l}\text { Signifier } \\
\text { (penanda) }\end{array}$ & $\begin{array}{l}\text { Signified } \\
\text { (petanda) }\end{array}$ & \\
\hline $\begin{array}{l}\text { Denotative Sign } \\
\text { (tanda denotative) }\end{array}$ & $\begin{array}{l}\text { Connotative } \\
\text { signified } \\
\text { (penanda } \\
\text { konotatif) }\end{array}$ \\
$\begin{array}{l}\text { Connotative Signifier } \\
\text { (Penanda Konotatif) }\end{array}$ \\
\hline \multicolumn{2}{|c|}{ Connotative Sign (Tanda Konotatif) } \\
\hline
\end{tabular}

Gambar 2. Peta Tanda Roland Barthes (Sobur, 2017)

Analisis semiotika milik Roland Barthes digunakan untuk melihat keterkaitan atau hubungan antara tanda-tanda yang ditunjukkan dalam karakter Captain Marvel. Selain itu analisis semiotika ini memungkinkan peneliti untuk mengkritisi mitos-mitos ataupun ideologi yang muncul dalam karakter Captain Marvel.

\section{HASIL PENELITIAN DAN ANALISIS}

Hasil penelitian terbagi menjadi tiga bagian yaitu analisis denotatif, analisis konotatif, dan analisis mitos.

\section{Analisis Denotatif}

Pada dasarnya, denotasi dapat didefinisikan sebagai pemaknaan umum dari apa yang bisa dilihat dan didengar oleh indera manusia, baik dalam bentuk audio maupun visual. Hal ini pastinya tergantung pada pemaknaan secara umum apa yang menjadi pandangan masyarakat sekitar.

Temuan denotatif pertama dalam penelitian yaitu, Captain Marvel sebagian besar dalam film ditampilkan di depan karakter lain dengan arah angle pengambilan gambar secara low-angle ke arahnya. Pengambilan gambar seperti ini merupakan posisi pengambilan gambar lebih rendah dibandingkan objek.

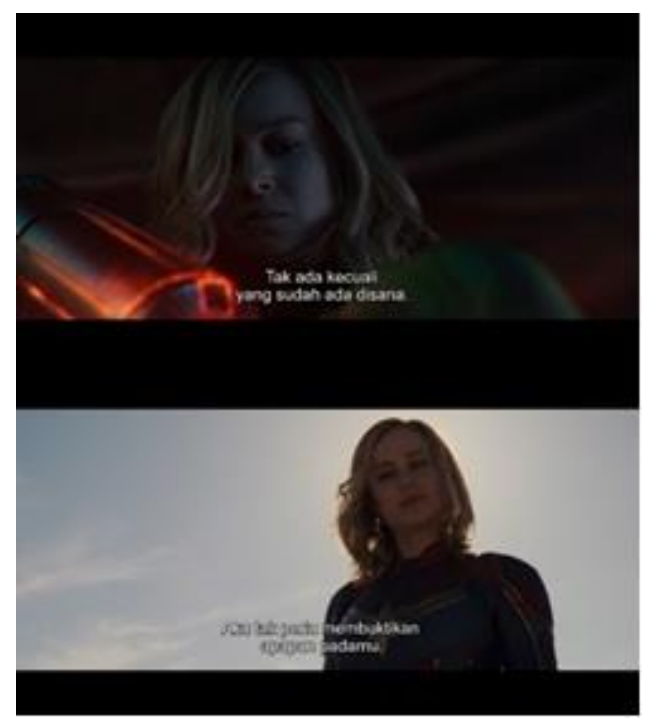

Gambar 3. Beberapa contoh adegan dalam Captain Marvel yang diambil dengan teknik low-angle. Sumber: Film Captain Marvel 
Selain sering ditampilkan melalui teknik pengambilan gambar low-angle, Captain Marvel juga sering kali ditampilkan berdiri di depan karakter lainnya dalam film atau berada di tengah-tengah layar.

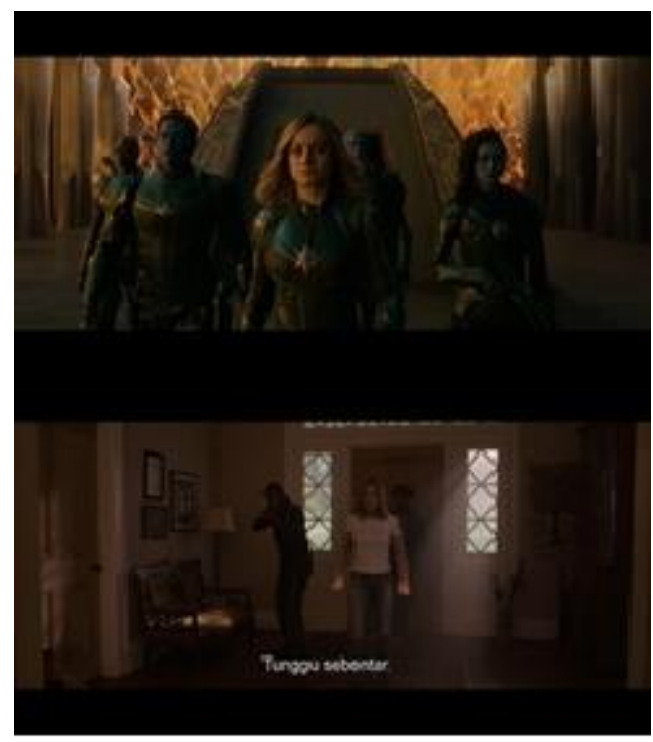

Gambar 4. Beberapa contoh adegan dalam Captain Marvel di mana posisi Captain Marvel berada di depan karakter lainnya. Sumber: Film Captain Marvel

Temuan denotatif kedua adalah Captain Marvel selalu digambarkan berdiri kembali ketika terjatuh atau gagal. Dalam film, Captain Marvel diceritakan sering mengalami kegagalan sejak ia masih kecil hingga ia menjadi dewasa. Setelah ia mengalami kegagalan, ia selalu bangkit dan kembali berdiri.
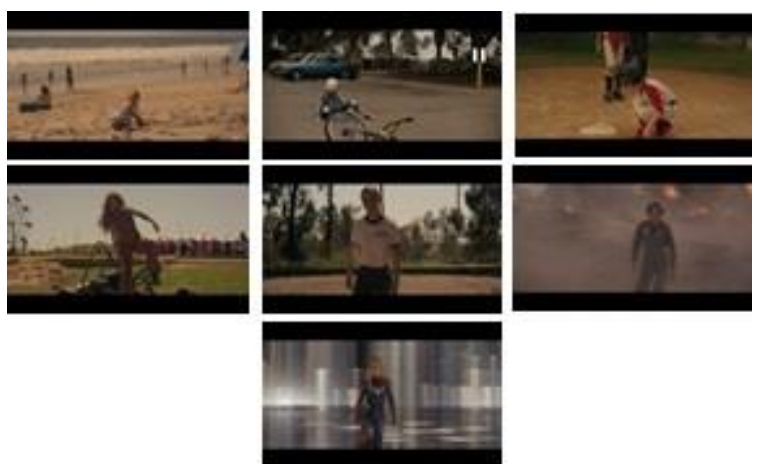

Gambar 5. Beberapa contoh adegan dalam Captain Marvel di mana ia selalu bangkit berdiri setelah jatuh atau gagal. Sumber: Film Captain Marvel

Temuan berikutnya yaitu Captain Marvel baru memiliki kekuatan super setelah ia terkena ledakan sebuah inti kekuatan. Kekuatan super yang dimiliki Captain Marvel bukanlah kekuatan yang berasal dari dalam dirinya sendiri, melainkan sesuatu yang ia dapatkan tanpa sengaja. Setelah mendapatkan kekuatan super, Captain Marvel kehilangan ingatan, kemudian dibawa pergi oleh pasukan Kree dan menjadi anggota mereka. Kekuatan super yang dimiliki Captain Marvel membuatnya mampu mengalahkan berbagai musuh dari bangsa Skrull dan pasukan Kree, serta ia berhasil menghancurkan pesawat-pesawat penghancur pasukan Kree.

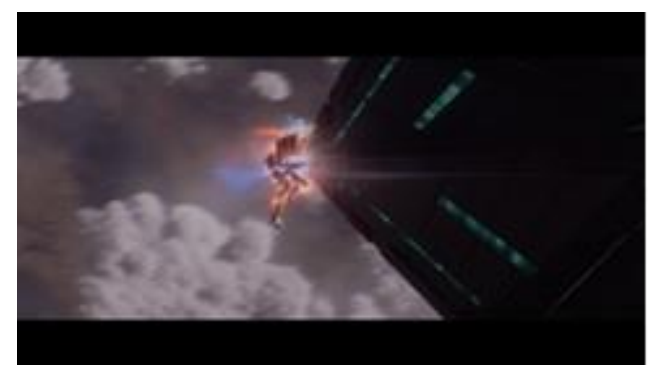

Gambar 6. Salah satu adegan dimana Captain Marvel menghentikan rudal raksasa pasukan Kree dengan kekuatan supernya. Sumber: Film Captain Marvel

Selain itu, dalam film, Captain Marvel diceritakan memiliki kemampuan bela diri yang luar biasa, ia selalu dapat mengalahkan musuh-musuh yang menghalanginya, baik secara perorangan maupun berkelompok. Sering kali Captain Marvel ditampilkan melawan musuhnya yang menyerangkan secara berkelompok dan selalu berhasil ia kalahkan.
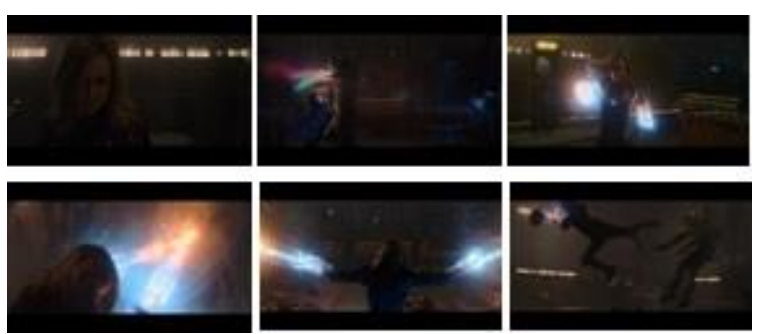

Gambar 7. Salah satu adegan dimana Captain Marvel berkelahi dengan sekelompok pasukan Kree secara bersamaan. Sumber: Film Captain Marvel

Setelah ingatannya kembali, Captain Marvel mengganti warna pakaiannya yang semula hijau dan merupakan warna bangsa Kree menjadi warna sesuai dengan lambang US Air Force, yaitu warna kuning keemasan, biru, dan merah sebagai warna kostum barunya. Warna ini dipilih ketika ia bersama dengan anak perempuan dari sahabatnya yang mengenakan kaos dengan lambang US Air Force.

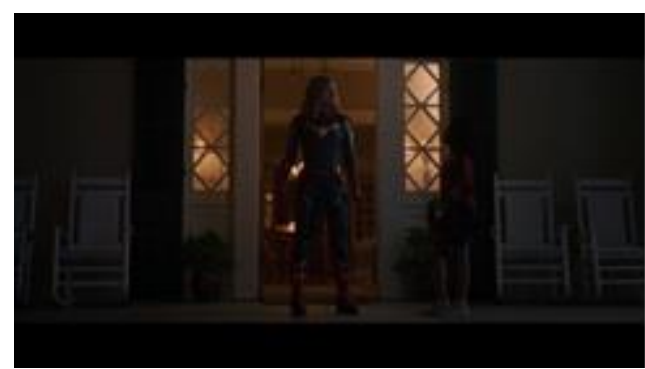

Gambar 8. Adegan di saat Captain Marvel mengganti warna kostumnya sesuai dengan warna dari lambang US Air Force. Sumber: Film Captain Marvel

Hasil denotatif di atas, merupakan hasil rangkuman dari keseluruhan adegan yang menjadi 
unit analisis dalam film Captain Marvel berjumlah 28 adegan / scene.

\section{Analisis Konotatif}

Setelah melakukan kajian denotasi, dalam proses analisis semiotika Roland Barthes, akan dilanjutkan dengan melihat kajian konotasi pada objek penelitian. Pada proses ini kajian yang dilakukan adalah untuk melihat makna yang memang ingin diungkapkan oleh pengarang atau pembuat film melalui gambar/shot ataupun scene. Pada makna konotasi di dalamnya terdapat petanda, penanda dan juga tanda.

Dalam analisis denotatif, ditemukan bahwa Captain Marvel sering kali ditampilkan dengan arah pengambilan gambar secara low-angle ke arahnya. Posisi pengambilan gambar ini bertujuan untuk menggambarkan kesan wibawa atau kekuasaan pada tokoh atau karakter dalam film (Ertanti, 2016). Selain itu pengambilan gambar low-angle ke arah Captain Marvel, dan penempatan sosoknya yang selalu berada di depan karakter lainnya, menunjukkan sosok utama dalam sebuah film dan menunjukkan kekuasaan maupun kekuatan yang dimiliki dibandingkan dengan karakter lainnya.

Analisis konotatif berikutnya terkait dengan sosok Captain Marvel yang selalu bangkit ketika jatuh menunjukkan sikap pantang menyerah meskipun ia perempuan yang sering dianggap lemah oleh lingkungannya. Dari berbagai bagian adegan dan dialog yang terdapat di dalam film, pada masa kecilnya, Captain Marvel sering kali ditekan dan dianggap tidak layak untuk melakukan kegiatan yang dianggap hanya mampu dilakukan oleh laki-laki. Hal ini menunjukkan bawa Captain Marvel berusaha untuk masuk dan melakukan kegiatan laki-laki sejak ia masih kecil hingga ia dewasa. Ia tidak menyerah dengan kata-kata demotivasi yang diberikan oleh laki-laki di sekelilingnya. Captain Marvel menunjukkan ambisinya yang tinggi untuk bisa sejajar dengan laki-laki di masanya. Hal ini bertentangan dengan salah satu unsur feminitas menurut Brownmiller (2013) yang menyatakan bahwa feminitas memperbolehkan perempuan untuk tidak mengikuti ambisi, bahwa memiliki sebuah ambisi bukanlah ciri feminin.

Selanjutnya terkait Captain Marvel yang mahir bela diri dan memiliki kekuatan super memiliki posisi yang lebih superior dibandingkan karakter laki-laki dalam film. Dari berbagai scene perkelahian menunjukkan salah satu karakter yang berbeda dari diri Captain Marvel sebagai perempuan yang ditampilkan di media. Selama ini menurut Thornham (2010) perempuan seringkali ditindas dalam industri film. Perempuan sering ditindas dengan diperankan sebagai citra-citra palsu sebagai objek. Dalam hal ini yang dimaksud sebagai objek yaitu objek seks atau objek penggoda pria. Sedangkan dalam film ini Captain Marvel sama sekali tidak ditampilkan sebagai objek seks.
Dalam beberapa scene, Captain Marvel menjadi sosok yang pertama kali rekan atau musuhnya lakilakinya untuk bertarung. Hal ini bertentangan dengan salah satu konsep feminitas yang bertentangan dengan feminism, di mana Brownmiller (2013) menyebutkan bahwa unsur feminitas dalam suara seorang perempuan bukan hanya dilihat dari seberapa halus ia berbicara, namun juga bagaimana ia berbicara. Selanjutnya ia mengatakan bahwa ada anggapan bahwa tidaklah feminin untuk mengekspresikan opini yang kuat, meskipun mengenai sesuatu yang tidak kontroversial.

Dalam adegan perkelahian, sering kali Captain Marvel terlihat ambisius, semangat dan termotivasi tinggi untuk membalas setiap pukulan, tendangan dan tinjuan dari musuhnya. Kemampuan Captain Marvel dalam bertarung menunjukkan kekuatannya yang setara dengan pria, di mana hal ini bertentangan dengan anggapan perempuan feminin menurut Brownmiller (2013) bahwa kebanyakan anak perempuan mendapatkan pengajaran tentang bagaimana bergerak yang baik ketika mereka kecil. Bahwa seorang perempuan harus bergerak secara halus, lemah lembut, perlahan bagai air yang mengalir, sedangkan berbeda dengan Captain Marvel yang terlihat mahir beladiri. Ia juga sering ditampilkan sebagai sosok yang kuat dan bisa mengalahkan musuh-musuhnya dengan mudah walaupun ia kalah dari segi jumlah. Hal ini menunjukkan bahwa Captain Marvel memiliki kekuatan di atas musuh-musuhnya. Hal ini menunjukkan sisi Feminisme Radikal yang ingin menghancurkan ideologi patriarki yang berarti kekuasaan laki-laki terhadap perempuan (Jones, Bradbury, dan Buotillier, 2016). Hal ini ditunjukkan dalam adegan ini dengan karakter Captain Marvel yang sangat kuat hingga dapat mengalahkan banyak laki-laki dalam perkelahian fisik.

Meskipun Captain Marvel sering ditampilkan sebagai karakter yang lebih kuat dibandingkan karakter laki-laki dalam film, juga terdapat berbagai adegan yang menunjukkan kesetaraan antara Captain Marvel dengan salah satu karakter laki-laki yaitu Nick Fury. Ketika terdapat adegan bersama dengan Nick Fury, sering kali teknik pengambilan gambar yang digunakan adalah eye-level-angle, yaitu posisi pengambilan gambar yang sejajar atau setara dengan objek yang diambil (Ertanti, 2016).

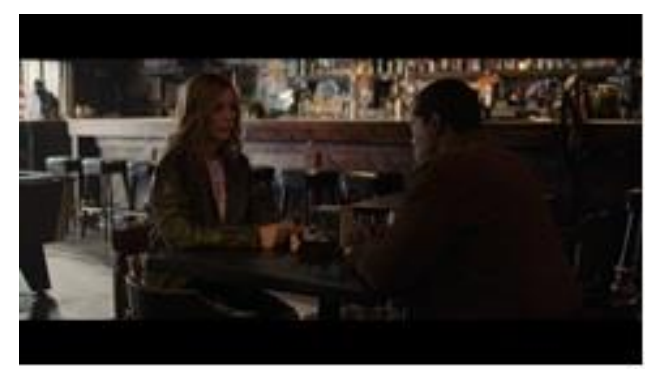

Gambar 9. Salah satu adegan di saat Captain Marvel berdiskusi dengan Nick Fury. Sumber: Film Captain Marvel 
Dalam adegan di atas ini Captain Marvel dan Fury duduk berhadapan dengan sejajar. Posisi duduk yang sejajar dengan pengambilan gambar dengan teknik medium shot, two shot, dan eye level menunjukkan kesejajaran posisi di antara kedua karakter yang berada dalam satu shot. Hal ini menunjukkan bentuk Feminisme Liberal di mana di mana perempuan dapat hidup setara dengan laki-laki.

Terkait pemilihan warna kostumnya, Captain Marvel memilih warna merah yang melambangkan kekuatan dan energi, warna biru melambangkan kepercayaan, dan warna kuning melambangkan harapan (Ni Luh, 2010). Namun pemilihan warna yang berdasarkan lambang US Force tersebut, bukan saja tidak saja untuk menunjukkan harapan, kekuatan, dan kepercayaan, namun juga keberpihakan pada US Air Force.

\section{Analisis Mitos}

Berdasarkan hasil penelitian, ditemukan dua mitos yang terdapat dalam Film Captain Marvel terkait karakter Captain Marvel.

Mitos Pertama: Perempuan Dapat Menjadi Setara atau Lebih Hebat dari Laki-laki Jika memiliki Kekuatan Super

Film Captain Marvel adalah salah satu film yang mengangkat kepahlawanan perempuan di antara banyaknya film bergenre pahlawan bermunculan dengan laki-laki sebagai karakter utamanya. Kehadiran Captain Marvel sesungguhnya memberikan nafas baru bagi bagaimana sosok perempuan ditampilkan di media. Selama ini perempuan sering kali ditampilkan sebagai sosok yang lemah dan membutuhkan pertolongan. Mereka membutuhkan laki-laki untuk bahagia atau untuk menolong mereka keluar dari permasalahan kehidupan.

Dalam dunia media, perempuan sering kali ditampilkan sebagai sosok Damsel in Distress yaitu menurut kamus bahasa Cambridge adalah sosok perempuan yang menghadapi masalah dan memerlukan bantuan laki-laki. Namun dalam film ini karakter perempuan utama yaitu Carol/Captain Marvel, bukanlah sosok yang membutuhkan pertolongan dari laki-laki. Hal ini menunjukkan ciri feminism liberal di mana perempuan dapat hidup setara dengan laki-laki. Madsen menyebutkan mengenai feminism liberal adalah usaha untuk mengubah patriarki bukan untuk mengubah struktur masyarakat yang didominasi oleh pria (2000).

Sedangkan menurut Ilyas dalam Rokhmansyah (2016), feminisme liberal beranggapan bahwa sistem patriarki dapat diubahkan dengan cara mengubah sikap masing-masing individu, terutama sikap kaum perempuan dalam hubungannya dengan laki-laki, karena itu perlu bagi perempuan untuk tidak bergantung pada pertolongan laki-laki. Namun sayangnya dalam film ini karakter perempuan utama digambarkan terlalu over powerful, sehingga ia baru dapat terlihat setara atau lebih dari laki-laki karena kekuatan super yang ia miliki, bukan karena kemampuan asli miliknya. Padahal tujuan utama Gerakan feminisme adalah untuk memperjuangkan kesetaraan. Secara sederhana Hooks (2000) mengatakan bahwa feminisme adalah sebuah gerakan untuk mengakhiri seksisme, eksplotasi dan tekanan seks. Penggambaran karakter yang terlalu over powerful seperti ini sebenarnya dapat mengubah asumsi mengenai kesetaraan.

Mitos Kedua: Perempuan Sulit Untuk Diakui Dalam Tempat Kerja

Dalam beberapa scene di film Captain Marvel, ditampilkan kesulitan yang dihadapi oleh Carol ketika ia berada di dalam pelatihan militer. Beberapa rekan dalam pelatihan militernya sering kali tidak mempercayai kemampuan fisik maupun kemampuan Carol dalam menerbangkan pesawat. Hal ini ditampilkan secara berulang dan juga sempat disampaikan oleh Maria Rambeau dalam salah satu dialognya dengan Carol. Meskipun film ini menceritakan kejadian di tahun 1996, namun film ini ditonton oleh banyak perempuan di tahun 2019, di mana mereka menerima pesan mengenai hal ini dan dapat memberikan dampak persepsi mengenai sulitnya kehidupan perempuan yang bekerja.

Padahal pada kenyataannya saat ini perempuan semakin banyak diterima di tempat kerja dan menempati posisi-posisi yang tinggi di tempat kerja. Menurut laporan Badan Pusat Statistik (BPS), terjadi pertumbuhan jumlah tenaga kerja perempuan dari 2018 ke 2019. Pada 2018, tercatat 47,95 juta orang perempuan yang bekerja. Jumlahnya meningkat setahun setelahnya menjadi 48,75 juta orang (2020).

\section{KESIMPULAN}

Berdasarkan hasil penelitian dengan menggunakan analisis semiotik Roland Barthes, ditemukan bahwa karakter Captain Marvel merepresentasikan dua nilai atau dua teori feminism yaitu feminisme radikal dan feminism liberal. Sisi feminisme radikal dalam film ini terutama terlihat dari kekuatan Captain Marvel yang lebih dari semua tokoh laki-laki di dalam film (over powerful). Hal ini menunjukkan ciri feminisme radikal yang ingin mengubah tatanan patriarki yang selama ini ingin membalik struktur posisi laki-laki dan perempuan di masyarakat. Selain itu sosok Captain Marvel sering kali ditampilkan berdiri atau berjalan di depan karakter lainnya termasuk karakter laki-laki dalam film ini. Penempatan sosok Captain Marvel yang selalu berada di depan ini, seakan-akan memperlihatkan bahwa ia adalah sosok pemimpin dan sosok pelindung dari karakter lainnya. Beberapa kali Captain Marvel juga ditempatkan pada posisi yang lebih tinggi atau terlihat lebih tinggi dari posisi karakter lainnya dengan arah pengambilan gambar dari low angle view di mana teknik ini biasa 
digunakan untuk memperlihatkan kekuatan dan kekuasaan karakter dalam sebuah film.

Karakter Captain Marvel juga merepresentasikan feminisme liberal di mana ia sebelum memiliki kekuatan super, selalu berusaha untuk mendapatkan posisi dan kesempatan yang sama dalam pekerjaan dan aspek kehidupan lainnya. Hal ini dapat dilihat dari adegan-adegan yang menampilkan usaha keras Carol/Captain Marvel untuk dapat diterima dan bisa menjadi pilot perempuan. Meskipun ia terjatuh,ia tetap berusaha bangkit hingga ia berhasil menjadi pilot. Selain itu sosok Captain Marvel ketika berbincang dengan karakter lainnya baik laki-laki ataupun perempuan, sangat sering diposisikan sejajar dalam duduk, maupun posisi kamera yang eye level dengan posisi mata penonton. Hal ini menunjukkan kesetaraan di antara dua karakter yang sedang berbicara.

Namun, dari berbagai representasi feminisme yang terdapat dalam karakter Captain Marvel, sayangnya sosok perempuan kuat harus ditampilkan sejajar atau lebih dari laki-laki karena ia memiliki kekuatan super, bukan karena kekuatan yang berasal dari dirinya sendiri. Hal ini tentu tidak sesuai dengan realitas yang ada di masyarakat di mana tidak dibutuhkan kekuatan super untuk dapat diakui dan dianggap setara dengan laki-laki.

\section{PENGAKUAN}

Penelitian ini dibiayai oleh Lembaga Penelitian dan Pengabdian Masyarakat (LP2M) Universitas Pembangunan Jaya sesuai dengan Kontrak Penelitian No. 004/PER-P2M/UPJ/05.19. Terima kasih yang sebesar-besarnya kepada LP2M UPJ atas hibah penelitian yang diberikan. Selain itu kami mengucapkan banyak terima kasih kepada dua orang mahasiswa yaitu Ifrikareen dan Kinanti yang telah membantu dalam proses pengambilan data.

\section{DAFTAR PUSTAKA}

Brownmiller, S. (2013). Femininity. New York: Open Road.

Ertanti, S. (2016). Representasi ToleransiBeragama dalam Film"Cahaya dari Timur: Beta Maluku. Diambil dari Universitas Walisongo: http://eprints. walisongo.ac.id/6470/1/COVER.pdf

Gamble, S. (2010). Pengantar Memahami Feminisme dan Postfeminisme. Yogyakarta: Jalasutra.

Hickey, W. (2014, Oktober 13). Comic Books Are Still Made By Men, For Men And About Men. diambil dari Fivethirtyeigth: https://fivethirtyeight.com/ features/women-in-comic-books/

Hollows, J. (2010). Feminisme, Feminitas, dan Budaya Populer. Yogyakarta: Jalasutra.

Hooks, B. (2000). Feminism is For Everybody Passionate Politics. London: Pluto Press.

Irawan, R. (2014). Representasi Perempuan Dalam Industri Sinema. Humaniora, 1-8.

Jones, P., Bradbury, L., \& Boutillier, S. L. (2016). Pengantar Teori-teori Sosial (Edisi Revisi). Jakarta: Gramedia.
Madsen, L. D. (2000). Feminist Theory and Literary Practice. London: Pluto Press.

Marvel. (2020). Explore The Universe. Diambil dari Marvel: https://www.marvel.com/explore

Marvel. (2020). Marvel Corporate Information. Diambil dari Marvel: https://www.marvel.com/corporate/ about/

McQuail, D. (2010). Mass Communication Theory 6th Edition. London: SAGE.

Movieweb. (2010, April 26). Kevin Fiege Talks Iron Man 2, The Avengers and More [Exclusive]. Diambil dari Movieweb: https://movieweb.com/exclusivekevin-fiege-talks-iron-man-2-the-avengers-andmore/

Ni Luh, D. I. (2010, Agustus 8). Warna. Retrieved from Repository ISI Denpasar: 1-3

Pusparisa, Y. (2020, Oktober 14). Perempuan Mendominasi Tenaga Kerja Usaha Jasa. Diabil dari Katadata: https://databoks.katadata.co.id/ datapublish/2020/10/14/perempuan-mendominasitenaga-kerja-usaha-jasa

Rokhmansyah, A. (2016). Pengantar Gender dan Feminisme. Yogyakarta: Garudhawaca.

Sobur, A. (2017). Semiotika Komunikasi. Bandung: Remaja Rosdakarya.

Thornham, S. (2010). Teori Feminis dan Cultural Studies. Yogyakarta: Jalasutra.

Watson, A. (2020, Januari 10). Superhero movies: domestic box office revenue. Diambil dari Statista: https://www.statista.com/statistics/311931/superher o-movies-box-office-revenue/ 